\title{
A case-based tool to assess college students' perceptions about ethical competence
}

Gonzalez-Cuevas, Gustavo ${ }^{a}$; Lopez del Hierro, Marta ${ }^{b}$ Martinez, Nieves ${ }^{b}$ and Hernando, Asuncion ${ }^{c}$

${ }^{a}$ Department of Psychology, European University of Madrid, Spain, ${ }^{b}$ Department of Clinical Medicine, European University of Madrid, Spain; and ${ }^{\mathrm{c}}$ Department of Pharmacy and Biotechnology, European university of Madrid, Spain

\begin{abstract}
The main objective of this study was to design a new tool to explore the perception of professionally-related ethical values in Health Sciences undergraduate students. For this purpose, 24 conversational interviews, as well as an extensive literature review, were initially employed. Then, five ethical values were selected: respect for the patient, altruism, empathy, responsibility for my actions, and lifelong learning. Next, twenty cases with ethical dilemmas were created with protagonists pertaining to four degrees in the Health Sciences: Nursing, Dentistry, Physical Therapy, and Medicine. These cases were examined by professionals from these fields and presented to a sample of students to analyze their functioning. Our results indicate that the cases are easy to understand as most cases were identified correctly. Interestingly, students reported "respect for the patient" as the most important ethical value. The least important value was "altruism." This new tool adds a practical perspective based on clinical cases with real-life dilemmas. Further studies are needed to continue exploring this topic.
\end{abstract}

Keywords: ethical values; ethical competence; ethical learning; college learning 


\section{Introduction}

Democracies in the 21st century are pluralistic societies in which citizens accept moral standards based on human rights and countries' constitutions. Today, our universities, undoubtedly, are also in need of educating these responsible citizens for an ethical commitment to serving public service (Martínez, Buxarrais, \& Esteban, 2002).

Generally speaking, European countries have recently witnessed a dramatic growth in research production in educational competencies, coinciding with the start of the European Higher Education Area (EHEA), the result of the political will of 48 countries whose aim is the advance of higher education (Trilla, Jover, Martinez \& Romaña, 2011; Naval, Garcia, Puig \& Santos, 2011; Martinez, 2008; Fabregat \& Perez-Cabrera, 2008; Martinez \& Esteban, 2005; Escamez, Ortega \& Martínez, 2005; Bolívar, 2005; Lozano, Boni, Siurana \& Calabuig, 2003). Importantly, EHEA has established that training and evaluation of future graduates must be based on formation in competencies. In this line, the Spanish National Agency for Quality Assessment and Accreditation (ANECA, in Spanish) also considers the training in competencies as assurance of quality results and one of the instructor priorities, even if this implies a deep change in the current way of teaching (Montemurro et al, 2013).

The field of health care raises numerous ethical concerns. Accordingly, Health Sciences students should comprehend what the values accepted in society are and be trained in those directly linked to their particular profession. This way, they may become better professionals able to act on ethical values held by their patients and their own. To the best of our knowledge, no studies exist regarding ethical values related to a professional context in college students. The aim of this study, therefore, was to design the first tool to assess the perception of ethical values in a professional context by undergraduate students in the Health Sciences.

\section{Methodology}

Initially, a qualitative study was conducted in which university students maintained conversational interviews with the aim of identifying, in a general way, the ethical values they considered more important to become good professionals (Hernando et al, 2014). An accidental and purposive sample of twenty-four first-, second-, and third-year students of Health Sciences (Medicine, Physical Therapy, and Sports Sciences) was used. Their average age was twenty years of age, with equal sex proportions. These interviews were conducted by three researchers who collected all the comments and ideas of the students for discursive representation analysis. This data was also complemented with a literature review on the most relevant ethical values for the professional world (Mercader, 2006; Montemurro, 2013). 
Taken together these two sources of information, we identified five ethical values that were found repeatedly: respect for the patient, altruism, empathy, responsibility for my actions, and lifelong learning.

Next, definitions for each of the selected values were created as follows:

Respect for the patient: respect for the patient is not only courtesy and politeness that certainly must preside over the relationship of the health professional with their patients, but also the absence of discrimination, either external/objective (race, religion, social and economic situation) or internal/subjective (feelings that the patient inspires to the health professional or the illness that the patient is suffering from).

Altruism: capacity to act selflessly in benefit of others who need help.

Empathy: capacity to put yourself in someone else's shoes, to understand what goes through their mind, how and why they might feel that way, not from our personal perspective but taken into consideration their thoughts, beliefs and values.

Responsibility for my actions: to feel responsible for our own actions and decisions, assuming obligations that correspond to these professional roles maintained in a society.

Lifelong learning: personal commitment to a continuing professional development to improve the quality of the care provided to the patient. It implies to be properly updated on the scientific theoretical knowledge, and being able to apply this to their professions.

In order to assess how students respond to real ethical concerns, a questionnaire was designed containing a series of clinical cases with ethical dilemmas. The protagonists of the cases were professionals or students from several areas in the Health Sciences: Nursing, Physical Therapy, Dentistry and Medicine. A total of 20 cases (4 for each area) were used, all based on real cases. An example of a case is the following:

CASE 17: Nuria is a 4th-year undergraduate student in Dentistry. She is busy finishing up some school papers with a deadline for today. Her mentor at a clinic has just called her up requesting her help to perform a root canal this very same day. Nuria has serious doubts about her preparation to perform this technical procedure, but agrees on helping. At the clinic, even if her mentor has not arrived yet she agrees on starting the procedure trusting that her mentor will not be too late.

These cases were reviewed by a group of experts consisting of professionals from various degrees (i.e., Nursing, Physical Therapy, Dentistry and Medicine). Then, a group of 26 undergraduate Psychology students were used to validate this test in a pilot study. For each of these cases, students had to express their level of agreement with an ethical behavior (in a Likert scale ranging from 1, low agreement, to 5, high agreement) and categorize the case into five ethical values (i.e., respect for the patient, altruism, empathy, responsibility for my 
actions, and lifelong learning), for which definitions were provided. We were also interested in exploring if volunteering experience could be a factor to take into consideration.

Statistics tests such as Pearson correlation and student t-test were performed when appropriated with the statistical program SPSS (version 20). Data were represented as means (and standard deviations) and percentages.

\section{Results}

The sample was comprised of 26 undergraduate Psychology students in their third and fourth years. The average age was 26.12 , with $23 \%$ men and $77 \%$ women. A total of $11 \%$ of the students reported having participated in volunteering.

Table 1. Mean scores (and standard deviations=SD) for the cases

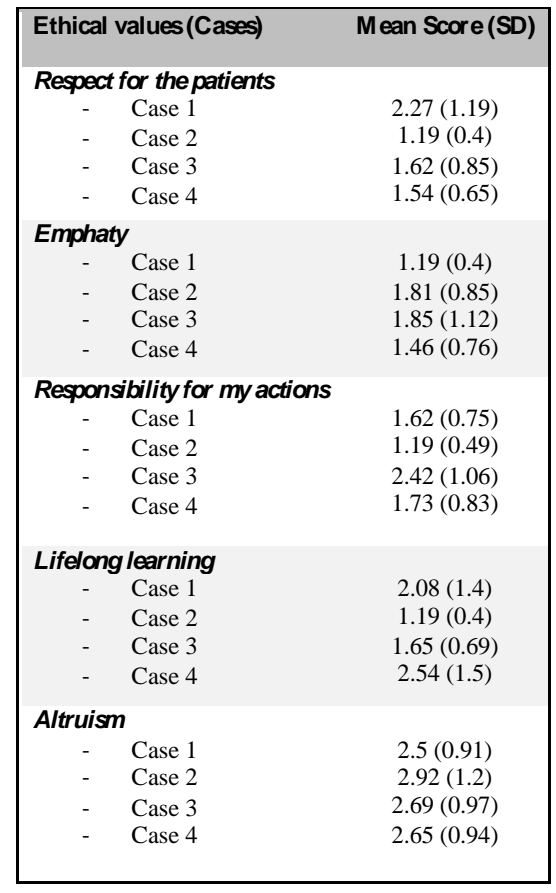

Mean scores (and standard deviations) for each ethical value (each corresponding to a dilemma or problematic situation) are presented in Table 1. Test scores ranged from 1.19 and 2.92, indicating that these third- and fourth-year students can identify ethical situations in a professional context. Indeed, "responsibility for my actions" was categorized correctly by most students, $88 \%$. "Lifelong learning" by $84 \%$, "respect for the patient" by $75 \%$, 
"empathy" by $70 \%$, and lastly, "altruism" by 57\%. "Altruism," for many students, was undistinguishable from "responsibility for my actions."

Interestingly, students categorized ethical values in this order of importance (see Figure 1):

(1) "Respect for the patient"

(2) "Empathy"

(3) "Responsibility for my actions"

(4) "Lifelong learning"

(5) "Altruism"

Finally, no statistical differences were found for sex, age, or volunteering effects.

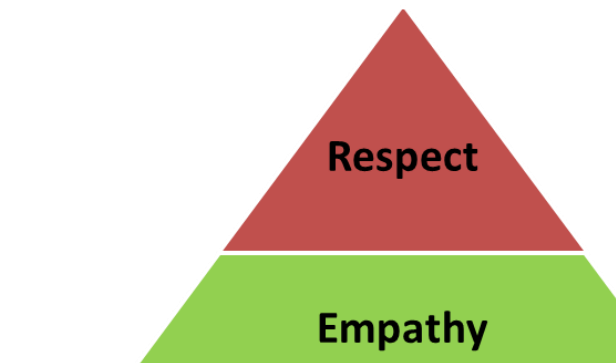

Empathy

\section{Responsibility}

\section{Lifelong learning}

\section{Altruism}

Figure 1. Students categorization of ethical values in order of importance (from top to bottom)

\section{Discusion}

The aim of this study was to design a new tool to explore the perception of ethical values in undergraduate students in the Health Sciences. Ethical competence in teaching universities tends to be considered under a general theoretical prism. The inclusion of clinical cases in this questionnaire, though, has favored a focus on professional values linked to more practical aspects of the field of ethics.

This pilot study, conducted in a small sample (so the questionnaire will need futher validation) permitted verifying clarity of the cases. For most cases, students identified correctly the ethical values related to either professional or student protagonists. These 
students reported that "respect for the patient" was the most important value. On the contrary, "altruism" was regarded as the least important. No statistical differences were found for sex, age, or volunteering experience.

Further studies are warranted in a bigger sample of over 500 students from several degrees to clarify differences in perceptions about ethical competence between first- and last-year students. This investigation is intended to answer the question of whether formative training can affect student perception of ethical values along years.

All in all, training of good health care professionals requires adding the ethical competence into the curriculum of Health Sciences degrees as well as extra motivation and implication by instructors. Here we presented a new tool to help understand the ethical competence from a practical perspective based on clinical cases with real-life dilemmas. However, further studies are needed to continue exploring this topic.

\section{References}

ANECA (2013). Guía de apoyo para la redacción, puesta en práctica y evaluación de los resultados del aprendizaje. Madrid

Bolivar, A. (2005). El lugar de la ética profesional en la formación universitaria. Revista Mexicana de Investigación Educativa, 10(24): 93-123

Escamez, J., Ortega, P., Martinez, M. (2005). Los valores de la educación en el Espacio Europeo de la Enseñanza Superior. El Espacio Europeo De Educación Superior. Valencia: Ed. Upv (Universidad Politécnica de Valencia), 165-198.

Fabregat, J., Perez-Cabrera, M. J. (2008). Valores y actitudes del ingeniero en las escuelas de ingeniería. In Proceedings of the Forth International Conference on Higher Education. Vol. 1. Ethics and Relevance of Scientific Knowledge: What Knowledge for what Society?, Barcelona

Hernando, A., Martiañez, N.L., Busto, M.J., Diaz, R., Martínez, N. y Díez-Vega, I. (2014). Percepción de los valores éticos de estudiantes de ciencias de la salud de la Universidad Europea. XI Jornadas Internacionales de Innovación Universitaria. Universidad Europea. Madrid

Hodelin Tablada, R. (2014). El profesor universitario en la formación de valores éticos. Educación Médica Superior, 28(1): 115-126.

Lozano, F., Boni, A., Siurana, J. C., \& Calabuig, C. (2003). La enseñanza de valores éticos en las carreras científico-técnicas. Experiencia del grupo de innovación docente en educación en valores en los estudios científico-técnicos en la UPV (Universidad Politécnica de Valencia). Monografías virtuales. Ciudadanía, democracia y valores en sociedades plurales, 3 .

Martinez, M., Buxarrais, M.R., Esteban, F. (2002). La universidad como espacio de aprendizaje ético. Revista Iberoamericana de Educación, (29): 17-43. 
Martinez, M., y Esteban, F. (2005). Una propuesta de formación ciudadana para el EEES. Revista Española de Pedagogía, 230: 63-84.

Martinez, M. (2008). Aprendizaje servicio y construcción de ciudadanía activa en la universidad: la dimensión social y cívica de los aprendizajes académicos. Aprendizaje servicio y responsabilidad social de las universidades, 11-26.

Mercader, V. (2006). Study of the ethical values of college students. Ed.D. University of South Florida.

Montemurro, D., Vescovo, G., Negrello, M., Frigo, A.C., Cirillo, T., Picardi, E., Chiminazzo, C., El Mazloum, D., De Caro, R., Benato, M., Ferretti, A., Mazza, A., Marcolongo, A. and Rubello, D. (2013). Medical Professional Values and Education: A Survey on Italian Students of the Medical Doctor School in Medicine and Surgery. N Am J Med Sci, 5(2): 134-139

Naval, C., Garcia, R., Puig, J., Santos, M. A. (2011). Ethical and civic education and the social commitment of university students. Encounters on education, 12, 77-91.

Trilla Bernet, J., Jover, G., Martinez, M., Romaña, T. (2011). La participación de los estudiantes en el gobierno y la vida universitaria. Encounters on Education, 12: 93-111. 